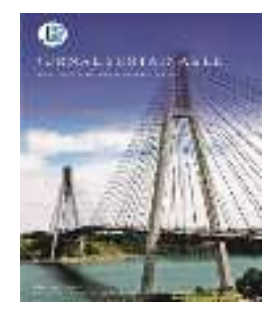

\title{
Pengembangan Sistem Informasi Praktik Industri dan Tugas Akhir Berbasis Web di Jurusan Pendidikan Teknik Elektro
}

\author{
Didik Aribowo ${ }^{1, *}$, Ratna Ekawati $^{2}$, Muhamad Otong $^{3}$, Rozeff Pramana ${ }^{4}$, Syifa Afrianti ${ }^{5}$ \\ 1,2,5 Jurusan Pendidikan Teknik Elektro, FKIP, Untirta \\ ${ }^{3}$ Jurusan Teknik Elektro, Fakultas Teknik, Untirta \\ ${ }^{4}$ Jurusan Teknik Elektro, Fakultas Teknik, Umrah \\ *Corresponding Author: d_aribowo@untirta.ac.id
}

\begin{abstract}
This study aims to develop an information system for industry practices and webbased final project in the electrical engineering education department. This study has the following objectives: 1) knowing the development of industrial practice information systems and web-based final projects in the electrical engineering education department, 2) knowing the feasibility of industrial practice information systems and the web-based final project in the electrical engineering education department. The research method used is the method of research and development of the 4D model. There are 4 stages: namely, define, design, development, disseminate. The results of this study are information systems for industry practices and web-based final projects. $85.3 \%$ of the large-scale trial results are included in the very feasible category.
\end{abstract}

Keywords: Information Systems, Research \& Development (4D Model).

Intisari - Penelitian ini bertujuan untuk mengembangkan sistem informasi praktik industri dan tugas akhir berbasis web di jurusan pendidikan teknik elektro. Penelitian ini memiliki tujuan yaitu : 1) mengetahui pengembangan sistem informasi praktik industri dan tugas akhir berbasis web di jurusan pendidikan teknik elektro, 2) Mengetahui kelayakan sistem informasi praktik industri dan tugas akhir berbasis web di jurusan pendidikan teknik elektro. Metode penelitian yang digunakan adalah metode penelitian dan pengembangan model 4D Tahapannya ada 4 tahap yaitu: define, design, development, desseminate. Hasil penelitian ini adalah sistem informasi untuk praktik industri dan tugas akhir berbasis web. Hasil uji coba skala besar $85,3 \%$ termasuk dalam kategori sangat layak.

Kata Kunci : Sistem Informasi, Research \& Development (Model 4D).

\section{Pendahuluan}

Sistem informasi memiliki komponen yang saling berinteraksi sehingga komponen sistem dapat bekerja dengan optimal, sistem informasi memiliki batasan sehingga ketika sistem informasi bekerja, sistem informasi dapat bekerja sesuai fungsinya tidak tumpang tindih antara fungsi satu dengam fungsi yang lainnya. Selain itu pada sistem informasi memiliki input yang akan diolah atau diprosess sehingga menghasilkan output yang berguna bagi penggunanya. Sebuah sistem menyajikan informasi untuk proses administrasi ketika menerima hasil dan melaksanakan operasionali lembaga, dimana sistem merupakan gabungan dari sekumpulan orang, teknologi informasi dan metode yang terorganisasi adalah sistem informasi. Sistem informasi dapat mempermudah dalam proses praktik industri (PI) dan tugas akhir (TA) di Jurusan Pendidikan Teknik Elektro (PTE), khususnya sistem informasi berbasis web [1].

Website yang dikembangkan pada penelitian ini menggunakan web dinamis, web dinamis dapat di update sesuai kebutuhan pengguna. 
D. Aribowo, R. Ekawati, M. Otong, R. Pramana, dan S. Afrianti, Pengembangan Sistem Informasi Praktik Industri dan Tugas Akhir Berbasis Web di Jurusan Pendidikan Teknik Elektro

Penggunaan website dipilih supaya memudahkan pengguna atau mahasiswa dalam mengakses sistem informasi PI dan TA. Website yang akan digunakan harus memuat informasi tentang PI dan TA.

Program PI merupakan salah satu program jurusan PTE yang dilaksanakan pertama kali pada tahun 2016. Bobot nilai 2 SKS, PI merupakan kegiatan kurikuler yang harusi diikuti oleh mahasiswa PTE. Program PI bekerjasama dengan perusahaan yang mencakup syarat dan relevan dengan jurusan PTE. Dalam mencari, memilih dan menempatkan mahasiswa untuk PI harus dikelola dengan baik melalui perencanaan, pengaturan, implementasi, penanganan dan pertimbangan yang cermat, agar mencapai tujuan secara efektif dan efisien. Dalam persiapan TA mahasiswa diharuskan melewati beberapa tahapan diantaranya yaitu seminar proposal TA.

Penyampaian informasi pada manajemen data PI dan TA menyita banyak waktu dan ternaga karena proses penyampaian informasi masih bersifat manual. Kemungkinan terjadinya kesalahan manusia (human error) dalam penyampaian informasi dan penyampaian informasi menjadi tidak akurat bisa terjadi.

\section{Kajian Pustaka}

Sistem informasi adalah suatu sistem dalam suatu institusi yang menyatukan kebutuhan pengolahan transaksi harian yang mendukung fungsi operasi organisasi untuk dapat menyediakan kepada pihak luar tertentu dengan informasi yang diperlukan untuk pengambilan keputusan [1].

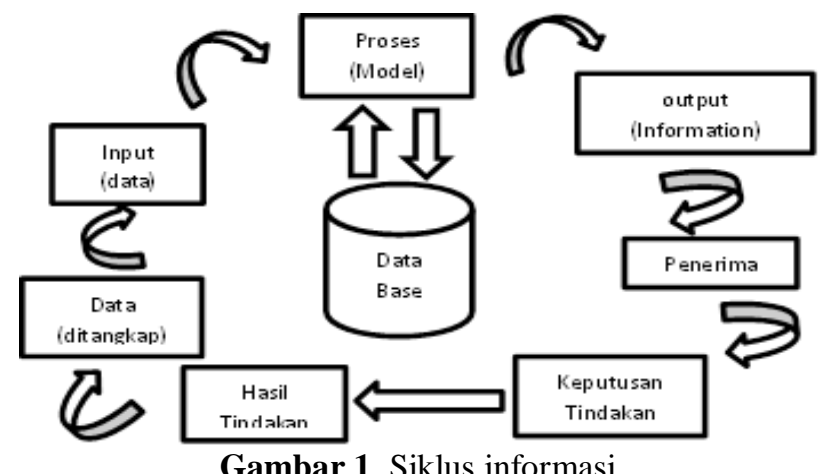

Gambar 1 menunjukan siklus informasi dimulai dari data diperoleh, diinput dengan menggunakan metode tertentu, diproses/diolah dengan menggunakan model pengolahan data sehingga menjadi informasi yang berupa tabel atau grafik yang didistribusikan kepada penerima yang dijadikan acuan dalam pengambilan keputusan dan mengambil tindakan, hasil tindakan dapat dijadikan data kembali dan terus melalui tahapan-tahapan dalam siklus informasi. (Sucipto, 2011:8)

Kualitas dari suatu informasi (quality of information) tergantung dari tiga hal:

1. Bebas dari kesalahan (akurat) informasi berkualitas jika informasi tersebut menunjukkan kebenaran.

2. Tepat pada waktunya (update) informasi berkualitas jika informasi tersebut disampaikan tepat waktu

3. Bermanfaat (relevan) informasi bermanfaat jika informasi tersebut memudahkan pengguna.

Pengembangan program sistem informasi ini menggunakan bahasa pemograman HTML dan PHP. HTML atau Hypertext Markup Language adalah bahasa standar yang digunakan untuk menampilkan halaman web. Fungsi dari HTML yaitu: [2]

a. Mengatur tampilan web dan isinya.

b. Membuat tabel dalam halaman web.

c. Mempublikasikan halaman web secara online.

d. Membuat form yang bisa digunakan untuk menangani registrasi dan transaksi melalui web.

e. Menambahkan objek-objek seperti citra, audio, video, animasi, java applet dan halaman web.

f. Menampilkan area gambar (canvas) di browser.

PHP adalah suatu bahasa scripting khusus digunakan untuk web delevopment, karena sifatnya yang server side scripting maka untuk menjalankan PHP harus menggunakan web server [2]. PHP dapat diintegrasikan dengan HTML, JavaScript, JQuery, Ajax. Pada umumnya $P H P$ lebih banyak bersama dengan file $H T M L$. Dengan menggunakan $P H P$ dapat membut website powerful yang dinamis dengan disertai manajemen databasenya. Pada awalnya PHP kependekan dari Personal Home Page (situs personal). PHP pertama kali dibuat oleh Rasmus Lerdorf pada tahun 1995. Pada waktu 
itu PHP masih bernama Form Interoreted (FI), yang wujudnya berupa berupa sekumpulan skript yang digunakan untuk mengolah data formulir dari web.

Proses pengelolaan data dan informasi tentang PI dan TA masih bersifat manual dan banyak kemungkinan human eror pada proses tersebut sehingga mahasiswa masih kesulitan dalam proses pengumpulan data dan mencari informasi tentang PI dan TA. Salah satu jalan penyelesaian masalah tersebut dengan mengembangkan sistem informasi PI dan TA di jurusan PTE, sistem informasi dapat diakses kapan saja dan tidak perlu membuang banyak waktu dan ramah lingkungan karena tidak banyak menggunakan kertas dan hemat biaya, serta diharapkan dengan adanya sistem informasi ini dapat mempermudah mahasiswa, dosen maupun staff dalam mencari informasi maupun proses dalam mengumpulkan data untuk PI dan TA.

Sistem informasi ini berisikan tentang konten yang dapat membantu dalam proses PI dan TA seperti informasi perusahaan, informasi praktik industri dan informasi tugas akhir. Sistem informasi ini diharapkan dapat membantu dan mempermudah mahasiswa dalam proses administrasi PI dan TA dimulai dari pendaftaran, surat surat dokumen-dokumen yang harus dibutuhkan dan informasi tentang seminar. Karakteristik sistem informasi berbasis web dapat memudahkan mendapatkan informasi, menghasilkan informasi yang berguna dan mengola data secara teratur sehingga tidak ada penduplikasian data.

Untuk mengimplementasikan sistem informasi PI dan TA ini tentunya harus dilakukan tahapan-tahapan dalam pengembangannya. Tahapan-tahapan ini dibuat untuk merapihkan sistem lama yang saat ini digunakan yang masih mengandalkan berkasberkas pengajuan dengan menggunakan kertas terkait PI dan TA.

Berdasarkan Gambar 2, sistem informasi dapat mempermudah mahasiswa dalam mengakses informasi tentang PI dan TA.

Sistem Informasi mempermudah mahasiswa mengakses informasi

\section{Realita di lapangan}

1. Belum tersediannya sistem informasi praktik industri dan tugas akhir berbasis web pada jurusan pendidikan teknik elektro

2. Sistem informasi tentang PI dan TA masih bersifat manual sehingga proses penyampaian informasi menyita banyak waktu dan tenaga.

3. Kurang terstrukturnya sistem informasi sehingga data yang disimpan bisa hilang dan dapat mengalami penggandaan data

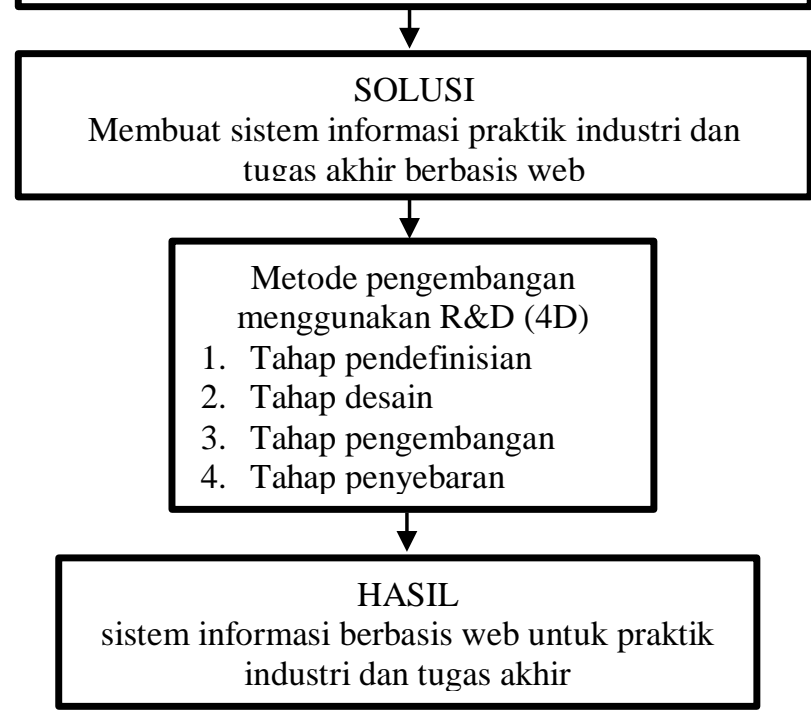

Gambar 2. Bagan kerangka pikir

Pengembangan sistem informasi PI dan TA didasari oleh permasalahan yang terjadi di jurusan PTE yaitu belum tersedianya sistem informasi untuk PI dan TA berbasis web sehingga mahasiswa PTE sulit mendapatkan informasi dan dengan sistem informasi yang masih manual Metode pengembangan yang digunakan yaitu 4D tahap yang dilakukan yaitu tahap pendefinisian, tahap desain, tahap pengembangan dan tahap penyebaran.

\section{Metode Penelitian}

Pengembangan sistem informasi PI dan TA berbasis web ini menggunakan metode Reseach and Development (R\&D). R\&D adalah metode penelitian yang digunakan untuk menghasilkan produk tertentu dan menguji keefektifan produk tersebut [3]. R\&D didefinisikan sebagai metode penelitian yang secara sengaja, sistematis, bertuan/diarahkan untuk mencari temukan, merumuskan, memperbaiki, mengembangkan, menghasilkan, menguji, keefektifan produk, model, metode/strategi/cara, jasa, prosedur 
D. Aribowo, R. Ekawati, M. Otong, R. Pramana, dan S. Afrianti, Pengembangan Sistem Informasi Praktik Industri dan Tugas Akhir Berbasis Web di Jurusan Pendidikan Teknik Elektro

tertentu yang lebih unggul, baru, efektif, efisien, produktif dan bermakna [4]. Dalam penelitian ini terdapat tahapan penelitian dalam flowchart sebagai berikut:

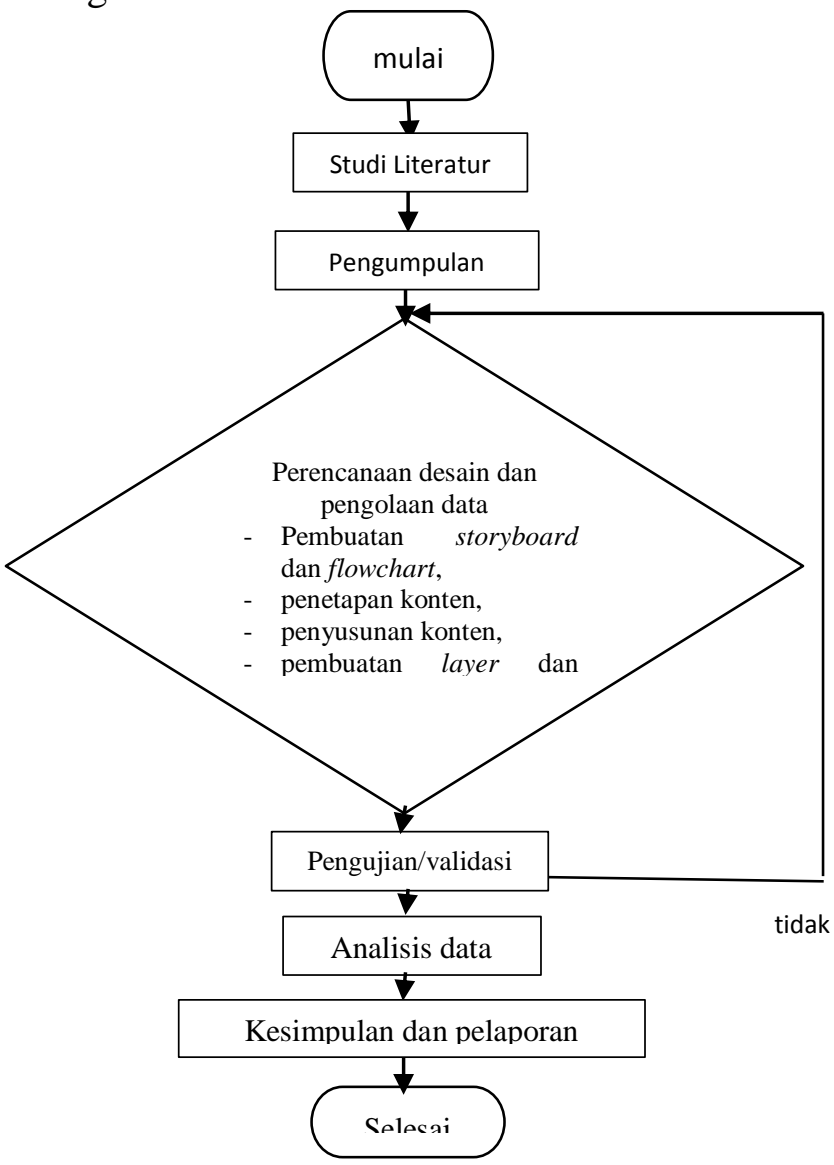

Gambar 3. Flowchart penelitian

Ada beberapa model prosedur pengembangan salah satunya adalah model pengembangan 4D, model ini dapat di implementasikan untuk mendesain dan mengembangkan sistem informasi. Model 4D dikembangkan oleh Thiagarajan [5]. 4D terdiri dari 4 tahapan utama yaitu, Define (Pendefinisian), Design (Perancangan), Develop (Pengembangan) dan Disseminate (Penyebaran). Model 4D dapat dijelaskan sebagai berikut:

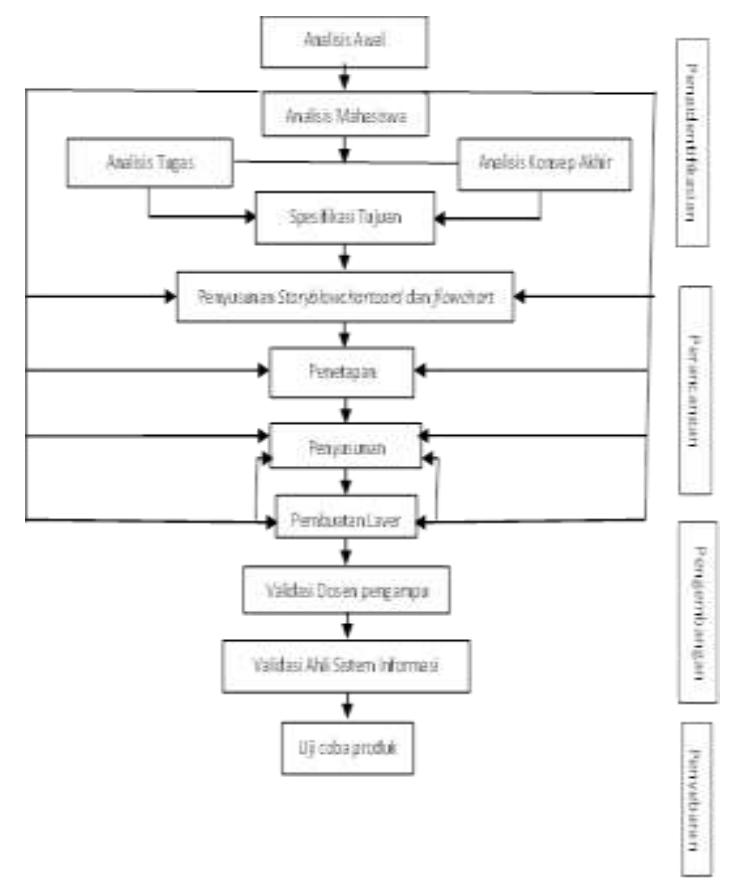

Gambar 4. Prosedur pengembangan model 4-d [5]

Dari gambar 4 dapat dijelaskan, bahwa tahap pertama 4D menentukan dan mendefinisikan masalah dan solusi yang tepat serta mengumpulkan berbagai informasi yang berkaitan dengan sistem informasi PI dan TA. Dalam tahap ini dibagi menjadi beberapa langkah yaitu analisis awal, analisis mahasiswa, analisis tugas, analisis konsep, dan spesifikasi tujuan.

Pada tahap perencanaan (desain) meliputi tahap pembuatan storyboard dan flowchart, penetapan konten, penyusunan konten, pembuatan layer, dan database. Sedangkan pada tahap pengembangan meliputi tahapan validasi dosen pengampu, validasi ahli sistem informasi, kemudian pada tahap penyebaran dilakukan uji coba produk.

\section{Hasil Dan Pembahasan}

Berdasarkan penelitian yang telah dilakukan yang berupa pengembangan media sistem informasi PI dan TA berbasis web bertujuan untuk mengembangkan sistem informasi PI dan TA di Jurusan PTE. Selain itu penelitian ini bertujuan untuk mengetahui kelayakan sistem informasi PI dan TA di jurusan PTE didapatkan hasil sebagai berikut :

A. Pengembangan Sistem Informasi PI dan TA

Pengembangan dan pembuatan sistem informasi PI dan TA berbasis web ini dilatar belakangi dengan permasalahan yang telah 
disebutkan di atas. Tujuan dari pengembangan sistem informasi PI dan TA berbasis web ini untuk mempermudah dan mempercepat proses pada PI dan TA bagi mahasiswa.

B. Penelitian ini menggunakan metode Research and Development $(R \& D)$ dengan model 4D.

1) Tahap pertama yaitu pendefinisian (Defain).

Terdapat 5 tahapan yang terdapat bada defain antara lain analisis awal, analisis mahasiswa, analisis tugas, analisis konsep, dan spesifikasi tujuan. Tahap pendefinisian dilakuakn dengan melakukan penyebaran angket studi pendahuluan dan wawancara kepada mahasiswa PTE serta dosen dan staff TU. Peneliti menyadari bahwa terdapat permasalahan yang dimiliki oleh mahasiswa pendidikan teknik elektro yaitu pada proses administrasi seperti pendaftaran-pendaftaran masih kurang efektif dan memakan banyak waktu saat proses administrasinya masih manual, data-data yang tersimpan masih kurang rapi karena tidak adanya database yang dapat menyimpan data tentang PI dan TA.

Selain itu mahasiswa masih kesulitan untuk mendapatkan informasi mengenai PI dan TA karena informasi yang didapatkan masih simpang siur dan terjadinya miss komunikasi. Berdasarkan hal tersebut diperlukan sistem informasi PI dan TA yang dapat memberikan informasi dan menghemat waktu mahasiswa dalam proses PI dan TA serta dapat merapikan data-data yang diperlukan karena terdapat database yang berguna sebagai penyimpanan. Maka dilakukan penelitian dan pengembangan sistem informasi PI dan TA berbasis web sebagai media yang dapat memudahkan mahasiswa dalam proses PI dan TA sehingga diharapkan dengan dibuatnya sistem informasi PI dan TA berbasis web ini dapat menjadi solusi atas permasalahan yang ada Jurusan PTE.

2) Tahap kedua yaitu design (desain)

Tahap perancangan memiliki tahapantahapan yaitu penyusunan storyboard dan flowchart, penetapan konten, penyusunan konten, dan pembuatan layer dan database. Tahapan perancangan dimulai dengan pembuatan storyboard dan flowchart sebagai rancangan awal sistem informasi, penetapan konten dan penyusunan konten dibuat dari hasil saran dan pendapat mahasiswa, dosen serta staff TU. Tahap selanjutnya yaitu pembuatan layer dan database yang dibuat menggunakan software PHPDesigner8 untuk pembuatan layer dan software XAMPP dengan menggunakan webserver MYSQL untuk penyimpanan data. Hasil design berupa website sistem informasi PI dan TA.

Tahapan perancangan dimulai dengan pembuatan storyboard dan flowchart sebagai rancangan awal sistem informasi. Terdapat tiga user yang dapat mengakses sistem informasi yaitu admin, dosen dan mahasiswa. Berikut flowcart alur sistem informasi PI dan TA.

\section{a) Flowchart admin}

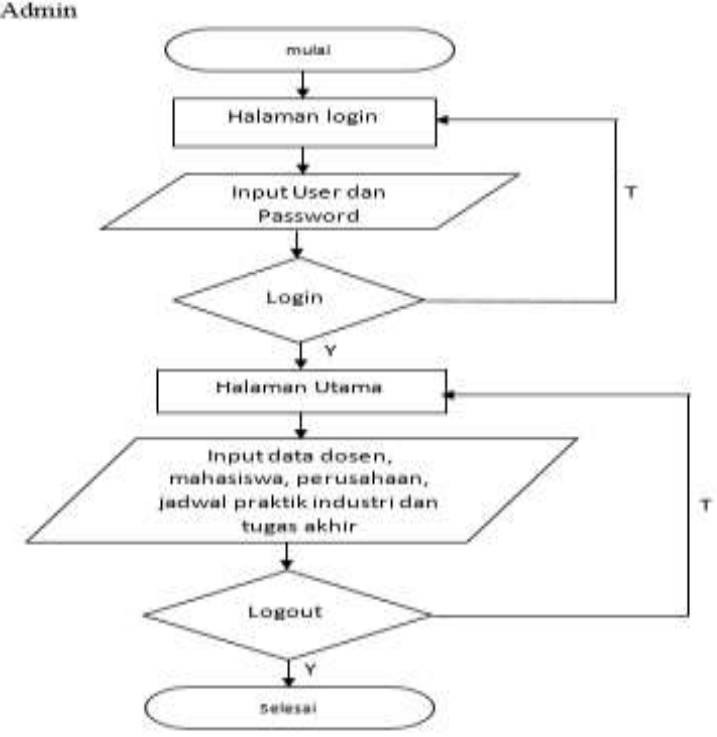

Gambar 5 flowchart admin

Alur flowchart pada gambar 5 dapat di jelaskan, Admin melakukan login dengan memasukan username dan passwordnya jika user dan passwordnya benar maka akan diproses lalu akan dilanjutkan ke halaman utama jika user dan password salah maka akan kembali ke menu login. Pada halaman utama terdapat beberapa menu bar antara lain Master data, PI dan TA. Pada menu Mater Data admin dapat menginputkan data dosen, mahasiswa, perusahaan dan jadwal seminar, pada menu PI dan TA admin dapat memantau dan melihat data-data mahasiswa yang sudah mengajukan dan mengupload berkas-berkas yang di perlukan pada PI dan TA. Admin dapat melakukan logout untuk keluar dari halaman tersebut.

\section{b) Flowchart mahasiswa}


D. Aribowo, R. Ekawati, M. Otong, R. Pramana, dan S. Afrianti, Pengembangan Sistem Informasi Praktik Industri dan Tugas Akhir Berbasis Web di Jurusan Pendidikan Teknik Elektro

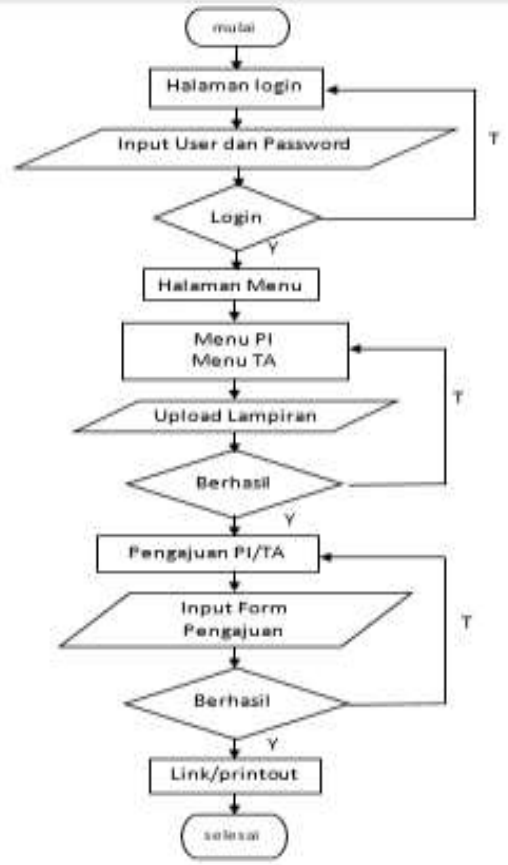

Gambar 6. flowchart Mahasiswa

Alur flowchart pada gambar 6 dapat di jelaskan, Mahasiswa login dengan memasukan username dan password. Jika login berhasil maka dilanjutkan ke halaman utama jika gagal maka akan kembali ke halaman login. Pada halaman utama ada menu bar yang berisikan menu PI dan TA. Pada menu PI terdapat menu pengajuan PI, pengajuan seminar PI, jadwal seminar PI, data dosen, data perusahaan, dokumen dan lampiran serta jurnal harian. sedangkan pada menu TA terdapat sub-menu pengajuan proposal skripsi, pengajuan seminar proposal skripsi, pengajuan seminar hasil skripsi, jadwal seminar dan sidang, serta dokumen/lampiran. Untuk mendaftarkan atau mengajukan PI atau TA mahasiswa mengupload lampiran atau persyaratan yang dibutuhkan setelah persyaratan berhasil diupload maka dilanjutkan ke menu pengajuan PI atau TA, mahasiswa mengisi pengajuan PI setelah berhasil mahasiswa dapat melanjutkan pembuatan surat dengan mengklik link eadministrasi.untirta.ac.id print out surat ijin PI untuk pendaftaran PI, sedangkan untuk pengajuan TA mahasiswa dapat memprintout surat verifikasi untuk pendaftaran seminar. Mahasiswa dapat melakukan logout untuk keluar dari halaman tersebut.

\section{c) Flowchart dosen}

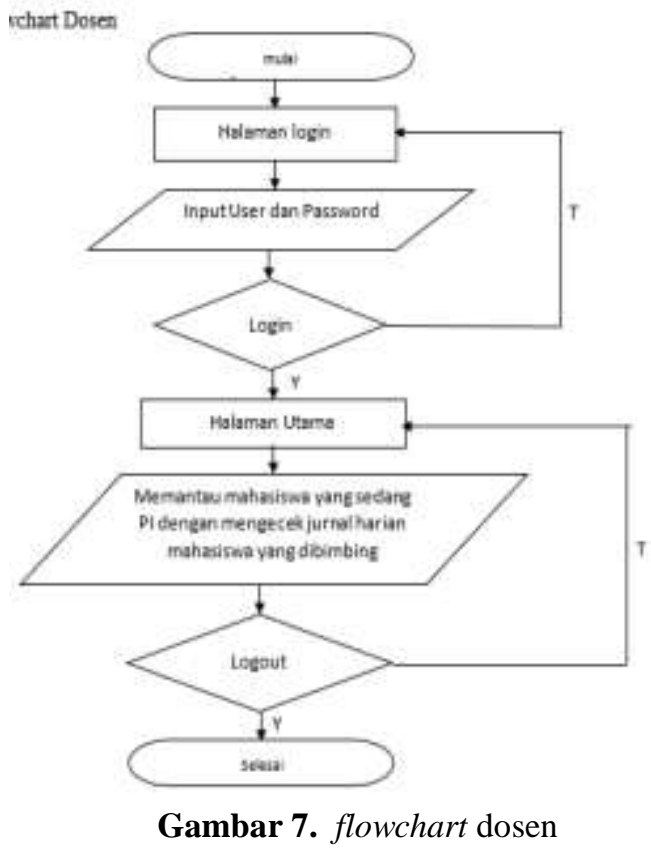

Alur flowchart pada gambar 7 dapat di jelaskan, dosen melakukan login dengan memasukan username dan passwordnya jika user dan passwordnya benar maka akan diproses lalu akan dilanjutkan ke halaman utama jika user dan password salah maka akan kembali ke menu login.

Tahap selanjutnya yaitu penetapan konten dan penyusunan konten dibuat dari hasil saran dan pendapat mahasiswa, dosen serta staff TU. Sistem informasi yang dibutuhkan ialah sistem yang memudahkan mahasiswa dalam proses PI dan TA, maka dari itu pada sistem diperlukan penyusunan konten yang diperlukan mahasiswa dalam proses PI dan TA.

Tahap selanjutnya yaitu pembuatan layer dan database yang dibuat menggunakan software PHPDesigner8 untuk pembuatan layer dan software XAMPP dengan menggunakan webserver $M Y S Q L$ untuk penyimpanan data. Hasil design berupa website sistem informasi PI dan TA.

Aplikasi ini digunakan peneliti untuk membuat web sistem informasi dengan menggunakan kodingan dalam pembuatannya. Jadi tahapan dalam pembuatan sistem informasi berbasis web yaitu pembuatan flowchart dan storybord untuk menetukan alur atau proses kerja sistem informasi dan penempatan menu serta icon lainnya yang diperlukan. Selanjutnya setelah flowchart dan storyboard selanjutnya mencari template yang sesuai dengan alur atau 
proses sistem informasi. Tahap selanjutnya yaitu membuat database, untuk membuat database aplikasi yang digunakan yaitu XAMPP dan webserver yang digunakan yaitu MYSQL.

Database dirancang sebelum dimasukan ke MYSQL. Tahap selanjutnya yaitu tahap pengkodingan, aplikasi yang digunakan dalam pengkodingan yaitu PHP Designer8 menggunakan bahasa pemograman PHP untuk proses data, HTML dan CSS untuk tampilan pada web dan JavaScript untuk membuat function animasi. Setelah pengkodingan selesai dibuat koneksikan database dengan sintaks web yang sudah dibuat.

Pada tampilan interface awal sistem informasi terdapat menu login dengan format judul web, logo, format login yaitu username dan password. Pada menu utama terdapatat menu - menu PI dan TA, untuk user admin dan dosen terdapat menu masterdata yang berfungsi untuk menyimpan data dosen, mahasiswa dan data perusahaan. Selain menu tersebut terdapat menu logout, help dan buku panduan bagi mahasiswa.

Pada tampilan interface menu gambar multimedia interaktif terdapat menu pilihan untuk memulai pembelajaran dengan gambar berupa rangkaian instalasi penerangan listrik. Menu pilihan tersebut berupa instalsi lampu pijar dengan sakelar tunggal, instalasi dua lampu pijar hubungan gudang, dan instalasi dua lampu pijar hubungan koridor atau rumah bertingkat.

Pada tampilan interface menu PI terdapat menu pendaftaran PI, pendaftaran seminar PI, jadwal seminar PI, dokumen, data perusahaan, data dosen dan jurnal harian. Setiap menu mempunyai fungsi yang berbeda. Pada tampilan interface menu TA terdapat menu-menu seperti pengajuan proposal skripsi, pengajuan seminar proposal, pengajuan seminar hasil, jadwal sempro, semhas dan sidang serta dokumen.

\section{3) Tahap ketiga yaitu development (pengembangan)}

Pada tahap pengembangan dilakukan validasi oleh dosen pengampu dan ahli media. Hasil dari validasi yang dilakukan oleh dosen pengampu dan ahli media menyatakan bahwa pengembangan sistem informasi PI dan TA berbasis web sangat layak. Validasi dosen pengampu dilakukan kepada koordinator PI dan koorsinator TA. Sedangkan validasi ahli media dilakukan kepada dosen teknik elektro. Hasilnya berupa saran, komentar dan masukan yang digunakan sebagai revisi terhadap sistem informasi. Tahap kelima yaitu evaluation (evaluasi).

4) Tahap Keempat yaitu Tahap Penyebaran (Desseminate)

Tahap penyebaran diujicobakan kepada mahasiswa PTE pada tahap uji coba ini di lakukan 2 tahap yaitu uji coba sekala kecil dan ujicoba skala besar.

Tahap Uji coba skala kecil dilakukan kepada 10 orang mahasiswa yang terdiri dari 2 orang mahasiswa 2014, 2 orang mahasiswa 2015, 2 orang mahasiswa 2016, 2 orang mahasiswa 2017, 2 orang mahasiswa 2018 yang bertujuan untuk mengetahui penilaian mahasiswa terhadap sistem informasi dan mengetahui saran dan komentar tentang sistem informasi yang akan dikembangkan sebelum diuji cobakan di skala besar. Tahap Uji coba skala besar Uji coba skala besar dilakukan pada mahasiswa angkatan 2014, 2015, 2016, 2017 dan 2018. Uji coba skala besar dilakukan setelah mengetahui kelayakan dan perbaikan dari uji coba skala kecil.

\section{Kelayakan Sistem Informasi PI dan TA di Jurusan PTE}

Penilaian kelayakan diambil dari tiga aspek penilaian yaitu, aspek kemenarikan, aspek kualitas teknik, dan aspek kualitas isi dan konten.

\section{a. Penilaian Ahli Media}

Sistem informasi dinilai dari tiga aspek yaitu aspek kemenarikan, aspek kualitas teknik dan aspek kualitas isi dan konten. Tahapan yang dilalui adalah melakukan penskoran respon angket yang dapat dianalisis dengan menghitung rata-rata jawaban berdasarkan skoring setiap jawaban dari responden yang akan dihitung menggunakan rumus [3] :

$$
\mathrm{P}=\frac{n}{N} \times 100 \%
$$

Keterangan:

P : Presentase respon

n : Jumlah skor yang diproleh

N : Jumlah skor Kriterium

$100 \%$ : Bilangan tetap 
D. Aribowo, R. Ekawati, M. Otong, R. Pramana, dan S. Afrianti, Pengembangan Sistem Informasi Praktik Industri dan Tugas Akhir Berbasis Web di Jurusan Pendidikan Teknik Elektro

Hasil yang diperoleh kemudian dipresentasikan sesuai dengan tabel berikut ini:

Tabel 1. Kriteria Uji Kelayakan

\begin{tabular}{cc}
\hline Prestase & Interprestasi \\
Pencapaian & \\
\hline $\mathbf{8 1 \% - 1 0 0 \%}$ & Sangat Layak \\
$\mathbf{6 1 \% - 8 0 \%}$ & Layak \\
$\mathbf{4 1 \% - 6 0 \%}$ & Cukup Layak \\
$\mathbf{2 1 \% - 4 0 \%}$ & Kurang Layak \\
$\mathbf{0 \% - 2 0 \%}$ & Tidak Layak \\
\hline
\end{tabular}

Skor penilaian ahli media menggunakan rumus di atas sehingga dapat dilihat hasilnya pada tabel 2 di bawah ini :

Tabel 2. Hasil validasi ahli media sistem informasi

\begin{tabular}{|c|c|c|c|c|}
\hline \multirow{2}{*}{$\begin{array}{c}\text { No } \\
\text {. }\end{array}$} & \multirow[t]{2}{*}{ Aspek } & \multicolumn{2}{|c|}{ Responden } & \multirow[t]{2}{*}{ Ket } \\
\hline & & $\begin{array}{c}\text { Dosen } \\
\text { Pengam } \\
\text { pu }\end{array}$ & $\begin{array}{c}\text { Ahli } \\
\text { Media }\end{array}$ & \\
\hline 1. & $\begin{array}{l}\text { Kemenarik } \\
\text { an }\end{array}$ & $85 \%$ & $100 \%$ & $\begin{array}{l}\text { Sangat } \\
\text { Layak }\end{array}$ \\
\hline 2. & $\begin{array}{l}\text { Kualitas } \\
\text { Teknis }\end{array}$ & $85 \%$ & $95 \%$ & $\begin{array}{l}\text { Sangat } \\
\text { Layak }\end{array}$ \\
\hline \multirow[t]{3}{*}{3.} & $\begin{array}{l}\text { Kualitas isi } \\
\text { dan Konten }\end{array}$ & $90 \%$ & $100 \%$ & $\begin{array}{l}\text { Sangat } \\
\text { Layak }\end{array}$ \\
\hline & Jumlah & $83,3 \%$ & $98,3 \%$ & $\begin{array}{l}\text { Sangat } \\
\text { layak }\end{array}$ \\
\hline & Rerata & \multicolumn{2}{|c|}{$90,8 \%$} & $\begin{array}{l}\text { Sangat } \\
\text { layak }\end{array}$ \\
\hline
\end{tabular}

Berdasarkan data yang diperoleh pada tabel 2, maka diperoleh kategori kelayakan oleh ahli media dan dosen pengampu dari aspek kemenarikan, aspek kualitas teknis, aspek kualitas isi dan konten dengan jumlah skor nilai dari dosen pengampu sebesar $83,3 \%$, jumlah skor nilai ahli media sebesar 98,3\%. Hasil dari jumlah skor nilai dari 3 ahli media kemudian diperoleh rerata skor untuk mengetahui kelayakan dari ahli media dengan hasil sebesar 90,8\%. Dari aspek kemenarikan berupa desain dan tampilan website menarik, presentase pada aspek kemenarikan yang dinilai oleh ahli media mendapatkan $100 \%$.

Presentasi yang diperoleh dari aspek kualitas teknis mendapatkan 95\%. Apek yang ke tiga yaitu aspek kualitas isi dan konten, pada aspek ini menilai proses pada sistem informasi, teks dapat terbaca dengan baik, dan kemudahan dalam mengakses sistem informasi, presentase penilaian untuk aspek kualitas isi dan konten mendapatkan $100 \%$. Jumlah keseluruhan untuk ahli media diambil dari rata - rata ketiga aspek mendapatkan presentase sebesar 98,3\% dari tabel kriteria uji kelayakan presentasi sebesar 98,3\% menyatakan sistem informasi PI dan TA berbasis web sangat layak untuk dikembangkan.

Pada penilaian yang dilakukan oleh dosen pengampu terdapat tiga aspek yaitu, aspek kemenarikan, aspek kualitas teknik, dan aspek kualitas isi dan konten. Aspek kemenarikan yang dinilai oleh dosen pengampu mendapatkan presentase sebesar $85 \%$ aspek kemenarikan ini menilai tampilan dan desain dari sistem informasi PI dan TA berbasis web. Penilaian kedua adalah aspek kualitas teknik yang mendapat presentase sebesar $85 \%$ aspek ini menilai fungsi setiap menu dan keeroran yang terjadi pada sistem informasi. Penilaian ketiga adalah aspek kualitas isi dan konten mendapat presentase sebesar $90 \%$ pada aspek ini menilai kualitas dari isi dan konten pada sistem informasi. Jumlah keseluruhan dari penilaian kelayakan dari koordinator PI dan koordinator TA mendapatkan presentase sebesar $83,3 \%$ jika pada tabel uji kelayakan menyatakan bahwa sistem informasi PI dan TA berbasis web sangat layak untuk dikembangkan.

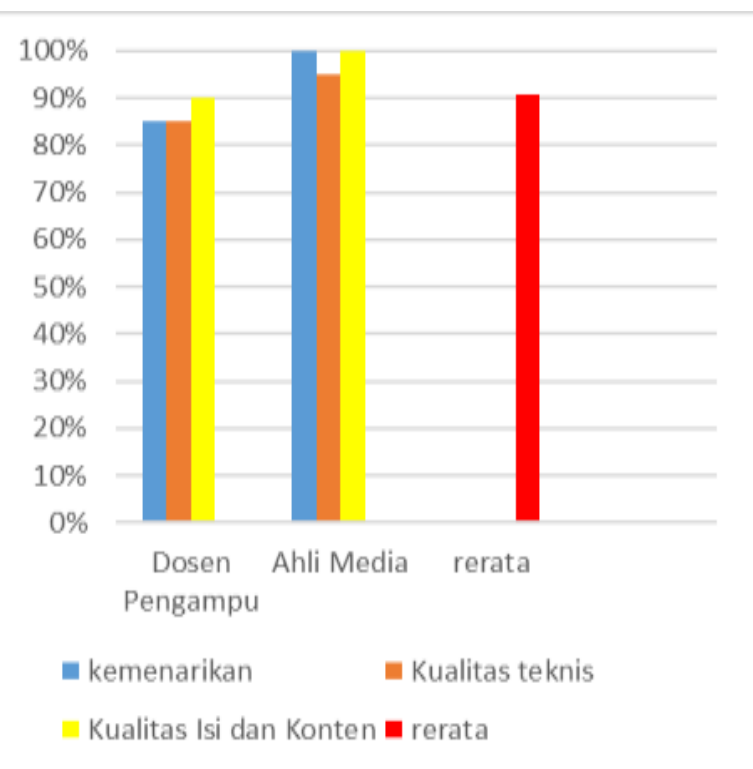

Gambar 8. prosentase hasil validasi dosen pengampu dan ahli media

\section{Uji coba skala kecil dan skala besar}

Uji coba skala kecil dilakukan terhadap 10 mahasiswa PTE, 10 mahasiswa tersebut terdiri 
dari 2 mahasiswa angkatan 2014, 2 mahasiswa angkatan 2015, 2 mahasiswa angkatan 2016, 2 mahasiswa angkatan 2017, 2 mahasiswa angkatan 2018.

Terdapat tiga aspek yang terdapat pada penilaian respon mahasiswa yaitu aspek kemenarikan, aspek kualitas teknis dan aspek kualitas isi dan konten.

Tabel 3. Uji Coba Skala Kecil

\begin{tabular}{clc}
\hline No. & \multicolumn{1}{c}{ Aspek } & Skor \\
\hline 1. & Kemenarikan & $86 \%$ \\
2. & Kualitas Teknik & $85,3 \%$ \\
3. & Kualitas Isi dan Konten & $89 \%$ \\
& Jumlah & $86,76 \%$ \\
\hline
\end{tabular}

Dalam aspek kemenarikan respon mahasiswa terhadap sistem informasi sebesar $86 \%$, aspek yang kedua adalah aspek kualitas teknik penilaian dari mahasiswa pada aspek kualitas teknik sebesar $85,3 \%$, aspek yang ketiga adalah aspek kualitas isi dan konten mahasiswa menilai isi dan konten pada sistem informasi, pada aspek ini penilaian dari mahasiswa sebesar $89 \%$. Jumlah kesuluruhan ketiga aspek tersebut didapatkan $86,76 \%$, kesimpulan pada penilaian respon mahasiswa dari uji coba skala kecil yang jika dilihat dari tabel uji kelayakan bahwa sistem informasi praktik industri dan tugas akhir berbasis web sangat layak dan respon dari mahasiswa menyatakan sangat layak dan mahasiswa paham akan fungsi dan proses pada sistem informasi.

Tabel 4. Uji Coba Skala Besar

\begin{tabular}{clc}
\hline No. & \multicolumn{1}{c}{ Aspek } & Skor \\
\hline 1. & Kemenarikan & $85,6 \%$ \\
2. & Kualitas Teknik & $86 \%$ \\
3. & Kualitas Isi dan Konten & $85 \%$ \\
& Jumlah & $85,5 \%$ \\
\hline
\end{tabular}

Aspek kemenarikan menilai desain dan tampilan sistem informasi respon dari mahasiswa terhadap aspek kemenarikan sebesar $85,6 \%$, aspek kualitas teknik menilai proses kerja sistem informasi berfungsi dengan baik ataupun tidak, respon mahasiswa terhadap aspek kualitas teknik sebesar $86 \%$. Aspek kualitas isi dan konten, respon mahasiswa terhadap aspek ini sebesar $85 \%$. Jumlah keseluruhan dari tiga aspek tersebut sebesar $85,5 \%$ dilihat dari tabel uji kelayakan didapatkan hasil sangat layak dan respon mahasiswa terhadap sistem informasi berdasarkan uji coba skala besar menyatakan sangat layak.

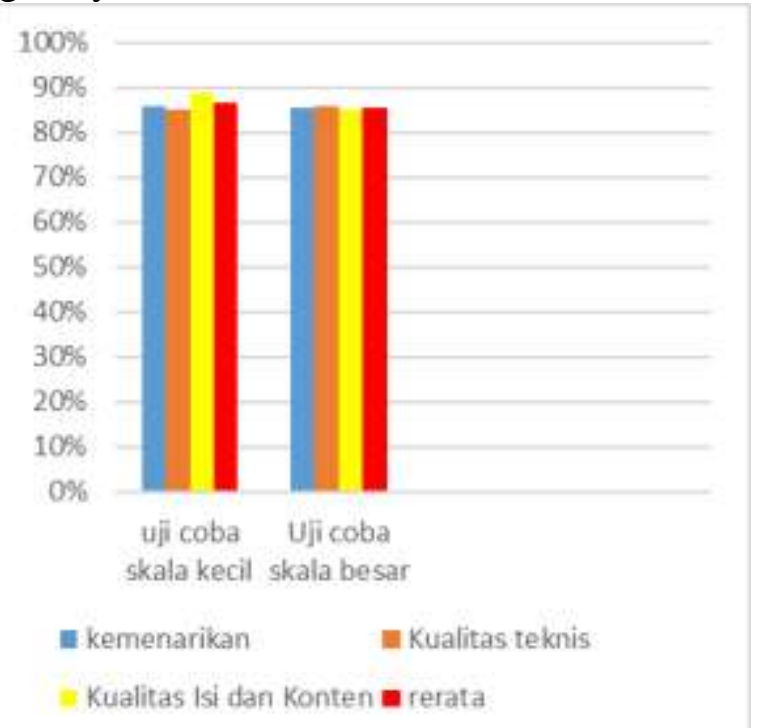

Gambar 9. presentase uji coba skala kecil dan uji coba skala besar

Dari gambar 9 dapat dilihat hasil grafik dari uji coba skala kecil dan uji coba skala besar. Rerata yang diperoleh dari uji coba skala kecil didapat dari 10 mahasiswa yang terdiri 2 orang angkatan 2014, 2 orang angkatan 2015, 2 orang angkatan 2016, 2 orang angkatan 2017 dan 2 orang angkatan 2018 mendapatkan 86,76\% menyatakan sangat layak untuk dikembangkannya sistem informasi, sedangkan rerata dari uji coba skala besar yang dilakukan kepada 80 responden diperoleh rerata sebesar $85,5 \%$ menyatakan sangat layak.

\section{Analisis hasil Pengembangan sistem informasi PI dan TA berbasis web}

Sistem informasi memiliki kelebihan, berikut kelebihan website yang dikembangkan:

a) Sistem informasi dapat memudahkan mahasiswa dalam proses PI dan proses TA dari pendaftaran hingga seminar.

b) Sistem informasi dapat memudahkan mahasiswa untuk mendapatkan informasi sehingga mengurangi terjadinya 
D. Aribowo, R. Ekawati, M. Otong, R. Pramana, dan S. Afrianti, Pengembangan Sistem Informasi Praktik Industri dan Tugas Akhir Berbasis Web di Jurusan Pendidikan Teknik Elektro

misscomunication serta menghemat waktu mahasiswa.

c) Sistem informasi memudahkan admin dalam menyimpan data-data, merapihkan data dan mencegah adanya penduplikasian data

d) Sistem informasi dapat memudahkan mahasiswa dalam pengisian jurnal harian agar ketika mahasiswa sedang PI tidak lupa dengan kegiatan yang dilakukan

e) Dosen dapat memantau mahasiswa melalui jurnal harian dan mengecek jurnal harian mahasiswa.

f) Mahasiswa dapat mendownload dokumen dan lampiran yang disediakan pada sistem informasi.

g) Sistem informasi dapat membantu tugas koordinator dalam proses PI dan TA.

Sistem informasi yang dikembangkan masih memilki banyak kekurangan. Kekurangan pada sistem informasi yaitu:

a) Sistem informasi belum terkoneksi langsung dengan e-administrasi sehingga mahasiswa diharuskan login kembali pada e-administrasi untuk proses pembuatan surat.

b) Sistem informasi diharuskan terkoneksi internet dalam pengaksesannya

c) Sistem informasi belum terkoneksi pada SISTA sehingga untuk pendaftaran sidang skripsi mahasiswa harus mengunjungi website SISTA

d) Kurang tertata tampilan pada sistem informasi pada setiap tampilan menu.

\section{PENUTUP}

Berdasarkan hasil penelitian dan hasil pengembangan sistem informasi PI dan TA berbasis web, maka dapat disimpulkan sebagai berikut :

1. Sistem informasi PI dan TA berbasis web ini dikembangkan berdasarkan metode Research and Development dengan model pengembangan 4D (Define, Design, Develop, Desseminatet). Proses pembuatannya terbagi menjadi beberapa tahap diantaranya yaitu (a) membuat storyboard dan flowchart (b) perancangan database, (c) pembuatan database, (d) pengkodingan pada aplikasi PHPDesigner8, (e) mengkoneksikan kodingan dengan database, (f) meng-online-kan website.

2. Tingkat kelayakan sistem informasi sesuai penilaian para ahli media dilihat dari aspek kemenarikan, aspek kualitas Teknis, aspek kualitas isi dan konten mendapatkan skor nilai $90,8 \%$ berada dalam range presentase $81 \%-100 \%$ berada dalam kategori 1 yaitu "sangat layak". Dalam artiannya yaitu sistem informasi ini dari keseluruhan aspek sangat layak digunakan untuk sistem informasi membantu dalam proses PI dan TA.

3. Tingkat kelayakan sistem informasi sesuai penilaian uji coba skala kecil dilihat dari aspek kemenarikan, aspek kualitas Teknis, aspek kualitas isi dan konten mendapatkan skor $86,76 \%$ berada dalam range presentase $81 \%-100 \%$ atau berada dalam kategori 1 yaitu "sangat layak".

4. Tingkat kelayakan sistem informasi sesuai penilaian uji coba skala besar dilihat dari aspek kemenarikan, aspek kualitas Teknis, aspek kualitas isi dan konten mendapatkan skor $85,5 \% \%$ berada dalam range presentase $81 \%$ - $100 \%$ atau berada dalam kategori 2 yaitu "Sangat layak".

\section{REFERENSI}

[1] Anggraeni, E,Y \& Irviani, R., 2017, Pengantar sistem informasi. Yogyakarta: Andi Offset

[2] Kawistara, P. H. \& J. K., 2017, Pemograman Web. Bandung: Informatika Bandung.

[3] Sugiyono, 2017, Metode Penelitian Kualitatif, Kuantitatif, dan R\&D. Bandung: ALFABETA.

[4] Sutono, D., 2007, Sistem informasi manajemen. Pusat pendidikan dan pelatihan pengawasan BPKP ISBN 979-3873-14-0.

[5] Thiagarajan, S., 1920, And Others Instructional Development for Training Teachers of Exceptional Children, (Mc) 